\title{
THE PRESIDENT AND CHOICES NOT TO ENFORCE
}

\author{
PETER L. STRAUSS*
}

The executive branch is often called upon to assess how a particular statute it is charged to administer fits within the larger framework of the law. Professor Dawn Johnsen's thoughtful analysis addresses an important subset of these challenges: situations in which the President believes a particular statute is inconsistent with one or another provision of the Constitution and, therefore, should not be enforced. ${ }^{1}$ My purpose here is to explore the context of executive non-enforcement more broadly, in a way that may help in understanding the particular problem she addresses.

Issues of constitutional structure and function are among the most daunting we face. We want to live in a rule-of-law society. We have a Constitution that we know and intend to be supreme. Yet its instructions are vague and dated. It does not in terms create a separation of powers, establish judicial review, define our day-to-day government, or much indicate the President's relationship to that government. Indeed, as Professor Walter Dellinger remarked at the opening of this conference, central questions respecting the presidency were not even addressed until the pressured final eleven days of the Constitutional Convention. After more than two centuries, some of the Constitution's most fundamental questions remain unanswered. Perhaps, as I understand Professor Alexander Bickel once remarked in another context, that is on the whole a good thing. Some questions are better left as questions, with fringes of uncer-

Copyright $(\mathrm{C} 2000$ by Peter L. Strauss

This comment is also available at http://www.law.duke.edu/journals/63LCPStrauss.

* Betts Professor of Law, Columbia University.

From 1975 to 1977, I served as general counsel to the Nuclear Regulatory Commission. That experience doubtless informs my view of executive government as variegated and of the President as acting chiefly in an oversight capacity, see, e.g., Peter L. Strauss, The Place of Agencies in Government: Separation of Powers and the Fourth Branch, 84 COLUM. L. REV. 573 (1984), in the same way that a person working in the Office of Legal Counsel, daily experiencing the important questions with governmentwide consequences and often directly providing counsel to the President, may focus on the President's authority and role.

Thanks are owing my fellow panelists and many others who spoke at or attended this symposium for helping me to see the issues addressed here more broadly, as to my colleague Professor John Manning. Additionally, I would like to thank Gaurav Shah, Columbia ' 00 , for research assistance.

1. See Dawn Johnsen, Presidential Non-Enforcement of Constitutionally Objectionable Statutes, 63 LAW \& CONTEMP. PROBS. 107 (Winter/Spring 2000). The exigencies of the editorial processes and the time at which various drafts were submitted have made this paper much more of a response to Professor Johnsen's conference paper than to what is printed here. For that, I ask both her and the reader's forbearance. Although at critical points her argument still appears to depend on understanding "laws" as if that term meant only "statutes" and not the Constitution or governing precedent, our readers could well wonder, in the end, whether there is much ground that separates us today. 
tainty, doubt, and play that provide flexibility and stability through changing times.

It is perhaps best to begin these impressionistic responses to Professor Johnsen's ambitious paper by stating some premises central to my thinking about these problems, premises about which we might disagree. First, the Take Care Clause-which ending Section 3 of Article II of the Constitution, might not be thought the most important in the eyes of its drafters-does not in terms direct the President himself to faithful execution of the laws. Between saying that the President "shall receive Ambassadors and other public ministers," and that he "shall Commission all the officers of the United States," it says that he is to "take Care that the Laws be faithfully executed." Thus, in ordinary Englishappropriate in this sense to its placement late in the text of Article II- the Clause imagines that others will do the actual executing and that the President will be overseeing those persons, ensuring that their execution is faithful. While early Attorneys General disagreed about just how directory that oversight could be, they nonetheless recognized that Congress could specify oversight, not personal execution, as the presidential role. ${ }^{3}$ Congress's statutory assignments of role-at least unless they are unconstitutional, and the Necessary and Proper Clause gives Congress broad discretion in making those assignmentsare a part of the laws, the faithful execution of which the President is enjoined to assure.

Second, appreciating the passive voice of the Take Care Clause permits us to see more clearly that the term it uses, "laws," is not a synonym for "statutes." "Laws" necessarily includes the Constitution. The Clause is actually the second place at which Article II refers to faithful execution. In the presidential oath, specified earlier in the article, the President undertakes that he "will faithfully execute the Office of President of the United States, and will to the best of [his] ability preserve, protect and defend the Constitution of the United States." Here, the diction is active, not passive, and its only reference to law is to the

2. U.S. CONST. art. II, $\S 3$, cl. 4 (emphasis added).

3. Thoughtful teaching materials on presidential authority, such as PETER M. SHANE \& HAROLD H. BRUfF, SEPARATION OF POWERS AUTHORITY (1995), compare Attorney General Wirt's advice to President Monroe that his role was to give "general superintendence" to those whom Congress had assigned executive duties, as "it could never have been the intention of the constitution ... that he should in person execute the laws himself," 1 Op. Att'y Gen. 624, 625 (1823), with Attorney General Taney's advice to President Jackson that he could lawfully direct a U.S. Attorney to discontinue an existing prosecution, 2 Op. Att'y Gen. 482 (1831). Taney's advice acknowledged, however, that "[t]he district attorney might refuse to obey the President's order; and if he did refuse, the prosecution, while he remained in office, would still go on." Id. at 489. That is, the President would assure the faithful execution of the laws by removing one who failed to follow his directions, rather than substituting his own decision. Attorney General Cushing, in advice to President Buchanan, later asserted that "no Head of Department can lawfully perform an official act against the will of the President," though acknowledging that "all the ordinary business of administration" is, in statutory terms, placed under the authority of the departments, not the President, and "may be performed by its Head, without the special direction or appearance of the President." 7 Op. Att'y Gen. 453, 469-71 (1855). All of these opinions, with helpful commentary, may be found in H. JEFFERSON POWELL, THE CONSTITUTION AND THE ATTORNEYS GENERAL (1999).

4. U.S. CONST. art. II, § 1, cl. 7 (emphasis added). 
Constitution, not to statutes. It would be strange indeed if, having taken that oath, the President were precluded from considering what would "preserve, protect and defend the Constitution" in the course of seeing to it that others were faithful in their performance of duty.

Finally, and in keeping with the Gordian character of this knot, in my judgment we need always to bear in mind the difference between the concrete means by which disputes about the legality of particular executive branch actions might be resolved, and our aspirational hopes for the President's own understanding of his proper function. In a wide range of circumstances, but not all, the courts will be able to say whether executive action was lawful or not. To conclude that a particular action was illegal, however, is not to say that it was offensive to the Constitution, as such. Moreover, Congress can significantly shape the courts' availability by the provisions it makes for direct review or for intermediary institutions like the Government Accounting Office (the "GAO"), whose actions can engender judicial proceedings. ${ }^{5}$ Although, as Professor Dellinger reminded us, one of the changes to the Constitution's provision for the presidency was to eliminate language permitting him to be removed for "maladministration," Congress has the raw power to impeach a sitting President for almost any reason - as it nearly did Andrew Johnson or, more recently, William Jefferson Clinton-whether or not its reason-in-fact constitutes "Treason, Bribery, or other high Crimes and Misdemeanors." Further, Congress has lesser political tools, such as the budget. The public, once, has the sanction of denying re-election. And there is the verdict of history. What seems important to bear in mind is that all of these devices are fallible. As Justice Jackson once famously remarked, the Supreme Court does not have the final word on constitutional meaning because it is infallible; rather, it is infallible only because it is final. ${ }^{7}$ That the courts regularly convicted persons under the Alien and Sedition $\mathrm{Act}^{8}$ did not establish its constitutionality in fact, or that President Thomas Jefferson was wrong to suspend its enforcement when he took office. That Andrew Johnson was almost impeached is certainly no proof that the Tenure in

5. Congress provided broadly in the Administrative Procedure Act for judicial review of agency action, including action "unlawfully withheld or unreasonably delayed." 5 U.S.C. $§ 706$ (1994). The Supreme Court, while generally presuming against review of executive branch enforcement decisions, see Heckler v. Chaney, 470 U.S. 821 (1985), has recognized that Congress may by statute provide for such review, see Dunlop v. Bachowski, 421 U.S. 560 (1975). Moreover, Congress opened the possibility of litigation to challenge executive actions involving use of the public fisc when it implicated the Comptroller General's office in disputes concerning the legality of executive branch expenditures. See, e.g., Alaska S.S. Co. v. United States, 290 U.S. 256 (1933); Ameron, Inc. v. United States Army Corps of Eng'rs, 809 F.2d 979 (3d Cir. 1986), dismissed on petitioner's motion, 488 U.S. 918 (1988); Lear Siegler, Inc. v. Lehman, 842 F.2d 1102 (9th Cir. 1988), partially vacated en banc, 893 F.2d 205 (9th Cir. 1989).

6. U.S. CONST. art. II, $\S 4$. Except in unusual cases, failure to execute the laws as Congress might prefer they be executed - a failure that encompasses slow, unenthusiastic, or obstructionist administration as well as statutory impoundment-does not fall within these constitutional grounds for impeachment. The Tenure in Office Act, for violation of which President Andrew Johnson was nearly impeached, in terms made violation of it a crime. Tenure in Office Act, ch. 154, 14 Stat. 430 (1867).

7. See Brown v Allen, 344 U.S. 443, 540 (1953) (Jackson, J., concurring in the result).

8. ch. 73,1 Stat. 596 (1798). 
Office Act ${ }^{9}$ was constitutional or that he erred in disobeying it—and the proof would be no better had one more senator voted to convict. ${ }^{10}$ Congress's impeachment votes no more establish constitutional propositions than its votes on ordinary statutes do. What we hope is that Congress's behavior, and the President's, will be influenced by thoughtful consideration of constitutional text as well as the possible retaliation of other branches, the voters, or future historians. Thus the question here is how we should prefer the President to imagine his role in a rule-of-law culture-not what he can get away with, not what the sanctions are, but what it is that his role under the Constitution, well-imagined, calls on him to do.

Let us start at a little distance from the Constitution, thinking about what wielding executive authority might entail in any legal culture committed to the rule of law. Problems of executive fidelity to law are hardly unique to our peculiar if enduring system of separated powers and constitutional judicial review. Resource constraints combine with a contemporary sense of the important in all societies, one imagines, to require prioritization. As a result, some laws are enforced less than others, and some not at all. Once the prosecutor has preferred, for example, prosecutions for the sale of narcotic drugs over those for the sale of contraceptives, once condoms have emerged discreetly onto the shelves of the local pharmacy, any society might prefer that the shift in policy be publicly known and adhered to, rather than subject its citizens to the hazards of prosecution-prosecution for what might be political or even disreputable reasons. ${ }^{11}$ Prosecutions for selling contraceptives ceased long before any theory of their constitutional impermissibility gained credibility. They ceased while those statutes remained in state criminal codes, politically quite safe from removal.

9. ch. 154,14 Stat. 430 (1867).

10. It would be a considerable mistake to consider Congress's possible impeachment practice simply as a legal determination rather than as one mixed with large, even overwhelming, elements of politics. Had the Senate voted to impeach President Andrew Johnson, that need not have reflected a judgment about the meaning of the Constitution. It certainly would not have determined, for the Court's later decision in Myers v. United States, the constitutionality vel non of congressional reservation of the right to participate in the removal of an officer who had been appointed with the "Advice and Consent" of the Senate. See generally Myers v. United States, 272 U.S. 52 (1926). Any such impeachment verdict would not have been subject to direct review-what my late colleague Telford Taylor used to describe as an "aconstitutional" question-but that would not have established any presumptive correctness in it as a reading of the constitutional text.

11. Professor Alexander Bickel famously discussed Poe v. Ullman, 367 U.S. 497 (1961), as a possible appeal to statutory desuetude. See Alexander M. Bickel, The Supreme Court 1960 Term Foreword: The Passive Virtues, 75 HARV. L. REV. 40, 58-64 (1961). Elsewhere in this issue, the papers on religion discuss a case, "Branch Ministries," that might be understood by some as such a case - the revival of enforcement of 26 U.S.C. $\S 501$ (c), denying tax exempt status to religious organizations participating in elective politics), in response to a "Christian Beware" advertisement urging readers not to vote for candidate Bill Clinton in light of his support of "policies . . in rebellion to God's Laws." Section 501(c) had not been applied to the many ministers, priests, and rabbis who had previously urged political positions on their flock, even when the proceedings were televised, with political candidates in attendance. That the action could be explained as a response to solicitations of "tax-deductible" contributions to support the ad campaign, as were not directly made in the other cases, will be an explanation for some-but even so, an explanation that concedes the sting of such an enforcement decision otherwise. 
So, too, the inevitable imperfections of legislating, even in a parliamentary democracy lacking either political separation between the executive and legislature or a tradition of constitutional review, mean prosecutors will regularly face choices about enforcement requiring them to resolve conflicts between two laws, neither of which has been explicitly repealed. Perhaps they will favor the new over the old, the specific over the general, or the solution more consistent with other laws generally. However they resolve such puzzles, they will have chosen not to enforce validly enacted statutes, ones a court might conclude remained in full force.

We have high stakes in the efficient and regular resolution of problems such as these. Prosecutorial discretion is made more hazardous, not less, if the prosecutor feels free at any point to call up some dusty provision of the criminal law in dealing with an enemy of the moment. That hazard is underscored by the corollary proposition, that executive judgments about which laws to enforce and how much effort to expend in enforcing them are presumptively unreviewable in the ordinary case..$^{12}$ To be sure, there are exceptions-patterns of execution that consistently privilege Irish over Chinese laundrymen, ${ }^{13}$ or legislative provision for review of enforcement choices in particular contexts. However, in general, neither courts nor legislatures invite such review. Permitting litigation about the government's priority choices usually promises more costs than benefits: It threatens to transfer the setting of public priorities to persons disappointed by the allocations made ${ }^{14}$ and it may give a tool for imposing diversion (and the associated added expense) of government effort to the very people the legislature has decided it is most important to control..$^{15}$

12. See generally Heckler v. Chaney, 470 U.S. 821 (1985).

13. See generally Yick Wo v. Hopkins, 118 U.S. 356 (1886).

14. As the Heckler v. Chaney Court stated:

The reasons for this general unsuitability are many. First, an agency decision not to enforce often involves a complicated balancing of a number of factors which are peculiarly within its expertise. Thus, the agency must not only assess whether a violation has occurred, but whether agency resources are best spent on this violation or another, whether the agency is likely to succeed if it acts, whether the particular enforcement action requested best fits the agency's overall policies, and, indeed, whether the agency has enough resources to undertake the action at all. An agency generally cannot act against each technical violation of the statute it is charged with enforcing. The agency is far better equipped than the courts to deal with the many variables involved in the proper ordering of its priorities. . .

In addition to these administrative concerns, we note that when an agency refuses to act it generally does not exercise its coercive power over an individual's liberty or property rights, and thus does not infringe upon areas that courts often are called upon to protect. Similarly, when an agency does act to enforce, that action itself provides a focus for judicial review, inasmuch as the agency must have exercised its power in some manner. The action at least can be reviewed to determine whether the agency exceeded its statutory powers. See, e.g., FTC v. Klesner, 280 U.S. 19 (1929).

Finally, we recognize that an agency's refusal to institute proceedings shares to some extent the characteristics of the decision of a prosecutor in the Executive Branch not to indict-a decision which has long been regarded as the special province of the Executive Branch, inasmuch as it is the Executive who is charged by the Constitution to "take Care that the Laws be faithfully executed." U.S. CONST., art. II, § 3; Heckler, 470 U.S. at 831-32.

15. Decisions to prosecute a person ordinarily can be challenged at the time of final resolution of the charge against the person proceeded against. 
For the President of the United States, these ordinary issues of choosing are overlaid by the systems of divided government and constitutional review. Unlike the Prime Minister of England, the President is not "of" the legislature and our expectation of him is that he will act as a check upon it, and vice versa. The obligation "to take Care that the Laws be faithfully executed" is in significant measure an expression of the President's unique authority in the allocated functions of government. Such unique or characteristic core functions of a branch, it can be argued, are precisely those whose exercise cannot be coopted by the other branches. Congress cannot decide who should be prosecuted, and neither can the courts. As the Supreme Court noted in Heckler v. Chaney, ${ }^{16}$ the "Take Care" Clause's allocation of oversight of such decisions to the presidency is precisely why such "decision[s] have long been regarded as the special province of the Executive Branch" and for that reason ordinarily beyond judicial review. ${ }^{17}$

This is a fairly strong proposition. Legislative granting of excessive discretion to the President in the area of rulemaking - a power to create rules under circumstances in which a court would find itself without standards by which to say whether or not these rules were authorized by law-would constitute an unlawful delegation. Yet the executive is not obliged to express reasons for its choices either to enforce against one person rather than another, or to emphasize one law over another in its allocation of governmental resources. That is its unique and constitutionally protected function. That function can, without giving rise to constitutional questions about delegation, be committed to the unreviewable discretion of the executive branch; it is no hindrance that a court might conclude that, in this respect, there is "no law to apply."

Congress has, on occasion, made such decisions reviewable. ${ }^{18}$ A painful footnote to Heckler $v$. Chaney hints that there might be limits to judicial reluctance to review, leaving open for future decision the "situation where it could justifiably be found that the agency has 'consciously and expressly adopted a general policy' that is so extreme as to amount to an abdication of its statutory responsibilities." ${ }^{19}$ Statutory impoundment on a large enough scale might draw judicial attention; the Administrative Procedure Act provides a handle for that in permitting review for agency action unlawfully withheld or unreasonably delayed. ${ }^{20}$

Yet we may confidently expect that review would be found foreclosed for a governmental choice to abandon enforcement of former 18 U.S.C. $§ 334$ (forbidding the mailing of "every article or thing designed, adapted, or intended for preventing conception" ${ }^{21}$ ), and instead enforce other provisions of the criminal code restricting use of the mails. Moreover, even a court able to conclude that

16. 470 U.S. 821 (1985) (concerned whether the FDA could be forced to take enforcement action with respect to a certain drug that was used for human lethal injections).

17. Id. at 832 .

18. See Dunlop v. Bachowski, 421 U.S. 560 (1975).

19. 470 U.S. at 833 n.4 (citing Adams v. Richardson, 480 F.2d 1159 (D.C. Cir. 1973) (en banc)).

20. See 5 U.S.C. $\S 706$ (1994).

21. Youngs Rubber Corp. v. C. I. Lee \& Co., 45 F.2d 103 (2d Cir. 1930). 
the limits of non-enforcement discretion had been crossed might find effective judicial relief impossible to construct; this is another reason we might suppose for judicial hesitation to announce that the obligation to "take Care" had not been faithfully carried out." In the courts of appeals, not in the Supreme Court, we can find accounts of "a 14-year struggle to compel the Secretary of Labor under the Occupational Safety and Health Act... to issue a field-sanitation standard providing access to drinking water and toilets for several million American agricultural workers" and to "end this disgraceful chapter of legal neglect," ${ }^{23}$ or of the Secretary of Agriculture's refusal to implement a 1978 statute providing the possibility of discretionary foreclosure and debt relief for farmers kept by "circumstances beyond the borrower's control" from meeting their farm-and-equipment secured obligations to the Farmers Home Administration. $^{24}$ The length of the struggle in the first case ${ }^{25}$ and the difference between delaying one foreclosure and securing more than the most grudging administration of this unwanted program in the second suggest the difficulties in believing that judicial oversight of the "take Care" obligation can be effective.

The years following these decisions have seen a Supreme Court less and less interested in the uses of the courts to protect the disadvantaged in their dealings with bureaucracy - a unifying theme of these two cases and others like themand more and more reluctant to oversee review of executive decisions that could be characterized as programmatic. ${ }^{26}$ The reluctance is connected both to expressions of doubt about the possible efficacy of judicial relief, and to strong statements about what belongs to the President-and, more broadly, to political processes-and not to the courts. Even when courts do intervene, what they determine is that executive authority has been wrongly exercised in the instance; that the Executive was legally in error does not establish that its action was unconstitutional. That is, so far as the courts have treated any such cases, they have addressed only statutory issues, implicitly conceding that they lie within the range in which the executive is entitled to err, without having to be said to have strayed beyond the proper constitutional dimensions of office.

Finally, we can consider another troubling area of conflict, executive-judicial conflict, that again suggests more scope for executive judgment about the demands of the law than Professor Johnsen's analysis seems to imagine. When a government agency has a legal question resolved against it in the district courts or courts of appeals, the geographical nature of judicial review and the extremely limited availability of Supreme Court review permit a practice known

22. See Allen v. Wright, 468 U.S. 1167 (1984) (remediability an essential element of standing).

23. Farmworker Justice Fund, Inc. v. Brock, 811 F.2d 613, 614 (D.C. Cir.), vacated as moot, 817 F.2d 890 (D.C. Cir. 1987).

24. Allison v. Block, 723 F.2d 631, 633 (8th Cir. 1983); $c f$. United States v. Markgraf, 736 F.2d 1179 (7th Cir. 1984).

25. The case began in the Nixon Administration and ended shortly before George Bush became President.

26. See, e.g., Manuel Lujan v. Defenders of Wildlife, 504 U.S. 555 (1992); Manuel Lujan v. National Wildlife Fed'n, 497 U.S. 871 (1990). 
as "non-acquiescence." The government, charged by Congress with uniform national administration of the law in question, may continue to adhere to its view-at least in cases it cannot be certain would be reviewed in a circuit court that has already ruled against it-in the hope of persuading another court to its view of the proper law. Second Circuit judgments are not binding in the Fifth Circuit, and if the agency believes it can prevail outside the Second Circuit, there is no obstacle to its trying. While not without its critics-particularly when adhered to after several defeats, or within the same circuit as had initially ruled-"non-acquiescence" has the imprimatur of the Supreme Court. ${ }^{27}$ That is, the executive branch is obliged to operate within the law, and ultimately it is for the courts to define those boundaries. Yet, as the judicial definition is taking shape, there is nonetheless substantial legitimate room for the executive branch to assert and persist in its own readings of legal authority. ${ }^{28}$

So far we have been talking about issues into which the Constitution does not much intrude, save in its assignment of executive functions to the President, not the Congress or the courts. The possibilities of divided government, as well as changes in public mood that occur over time, virtually ensure that the President's exercise of his functions will be out of step with the preferences of the present Congress, or what past Congresses may have wanted when enacting statutes that have not yet been repealed. As the Court has reminded us, our direct remedies for any failures these conflicts may represent lie more often in congressional oversight or the election booth than in the courthouse. Perhaps for just this reason, it does matter how the President imagines his function, ${ }^{29}$ and surely having professional advice of the highest intelligence-like the Dellinger

27. See United States v. Mendoza, 464 U.S. 154 (1984).

28. In the affirmative action panel in this symposium, participants discussed events after Hopwood v. State of Texas, 78 F.3d 932 (5th Cir.), cert. denied, 518 U.S. 1033 (1996). In the wake of the decision, the Department of Education communicated to its federal fund recipients in the Fifth Circuit that it regarded the opinion's broad language about the impermissibility of affirmative action programs as simply dicta, and that it would continue to enforce departmental regulations conditioning grants of federal money on the recipients' having such programs. The Solicitor General, having represented to the Supreme Court in his unsuccessful petition for certiorari that the effect of Hopwood would be to make the implementation of such programs impossible, reacted strongly when he learned of this letter, causing it to be withdrawn. Of course, the Court's very reason for denying certiorari might have been that it disbelieved those representations, or that it anticipated that in another, perhaps stronger, case, another federal court might reach the opposite result-even another panel of the Fifth Circuit, precipitating an en banc proceeding. Compare Texas v. Lesage, 120 S. Ct. 467 (1999) (weak claims of affirmative action on admissions summarily rebuffed by Court per curiam). For the Solicitor General, on the other hand, the risk of losing credibility with the Court must have seemed very severe-so severe as to warrant requiring the Department to administer its program differentially across the nation and to abandon what it regarded as still-necessary remedies for the lingering effects of racial discrimination in the Deep South. The Fifth Circuit panel's animadversions to the possibilities of punitive damages provided another strategic basis for counseling retreat. Yet, at the level of legal obligation, this dispute is one of those that plainly might have been taken as high as the President and resolved in favor of the Department, against the Solicitor General. For present purposes, the point is that neither outcome could be said in advance of ultimate judicial resolution to be wrong-an instruction to withhold enforcement of arguably valid regulations because one court had found them unconstitutional, or an instruction to continue their enforcement grounded in the President's own understanding of the Constitution's commands.

29. See Peter L. Strauss, Presidential Rulemaking, 72 CHI-KenT L. REV. 965, 984-86 (1997). 
memorandum ${ }^{30}$-is important to that. Yet it still comes down to a question of presidential attitude to task. That attitude cannot be commanded from another place, and any assessments of it—political, congressional, or judicial—are subject to the same human frailties, temptations, and risks of error as the presidency itself.

When we turn to the issues of constitutionality on which Professor Johnsen chiefly focuses, we encounter the additional difficulty that what "the laws" are, which the President takes an oath to assure will "be faithfully executed," is considerably more complex than it would be in, say, England. In the United States-a country with both a written constitution, constitutional review, and traditions of common law judging- "the laws" comprise the Constitution, statutes, and the existing body of judicial precedent. ${ }^{31}$ In relation to the Supremacy Clause of the Constitution and the courts' final authority to say "what the law is," statutory text is the least authoritative of these three sources. Once the courts have said what the Constitution means, an executive acts at his peril in taking actions, including enforcing statutes, that are inconsistent with that holding, whether or not the particular action or statute itself has previously been subject to constitutional challenge. ${ }^{32}$ Once the Supreme Court has said what a statute means, then in its view even a sensible alternative interpretation presented by executive authority lies beyond the pale..$^{33}$

These propositions illustrate, in my judgment, that there is no necessary inconsistency between the formulae Professor Johnsen has quoted from the Civiletti and Dellinger memoranda ${ }^{34}$ - the space within which she seeks to construct her sophisticated and interesting tertium quid. The phrase she quotes from Benjamin Civiletti's letter-written to Congress and so perhaps selfconsciously guarded-concerned the President's duty. ${ }^{35}$ Reflecting the Court's stare decisis practice ${ }^{36}$ and the liability of executive officers under Webster Bi-

30. 18 Op. Off. Legal Counsel 199 (1994) (memorandum from Assistant Attorney General Walter Dellinger) [hereinafter Dellinger Memorandum].

31. Any semantic argument that the scope of "the laws" does not extend to all three was surely settled by Erie R.R. Co. v. Tompkins, 304 U.S. 64 (1938). Moreover, recalling the President's executive role as primarily one of oversight—at least in those arenas where legality of action is most likely to be a central concern-should persuade us that to honor his oath of office, he must be able to consult the Constitution in seeing to the faithful execution of the laws by others. See supra text accompanying note 2.

32. Cf. Cooper v. Aaron, 358 U.S. 1 (1958); Zinermon v. Burch, 494 U.S. 113 (1990) (finding liability under 42 U.S.C. $\$ 1983$ for statutorily authorized action, where that action could be anticipated to be unconstitutional under the Court's due process jurisprudence).

33. See Neal v. United States, 516 U.S. 284, 285 (1996). Once the Court has determined a statute's meaning, other courts must adhere to the "ruling under stare decisis" and assess "an agency's later interpretation of the statute against that settled law." Id.

34. Respectively, 4A Op. Off. Legal Counsel 55 (1980) (memorandum from Attorney General Benjamin R. Civiletti) [hereinafter Civiletti Memorandum], and Dellinger Memorandum, supra note 30.

35. See Johnsen, supra note 1 , at 23 .

36. Under, e.g., Cooper, 358 U.S. at 1, stare decisis in its strongest form appears to demand adherence to Supreme Court constitutional interpretations as "the supreme law of the land," to which an oath of office to support and defend the Constitution commits its taker. Even if one accepted the view notably expressed by President Lincoln in relation to Dred Scott v. Sandford, 60 U.S. 393 (1856), that 
vens v. Six Unknown Named Agents of Federal Bureau of Narcotics ${ }^{37}$ (or, for state executive officials, section 1983), Civiletti uncontroversially advised that it is the President's duty to implement the Supreme Court's constitutional jurisprudence where, in his judgment, the application of that jurisprudence would be clear. ${ }^{38}$ The President has no right to implement a statute that he can say with confidence the courts would find unconstitutional. A statute granting the FBI the authority to batter down doors in the middle of the night without a search warrant or other arguable Fourth Amendment authority would not protect its agents from Bivens liability. Faithful execution of the laws plainly includes the Constitution as authoritatively interpreted by the courts and the Supremacy Clause that entitles the Constitution to prevail.

Walter Dellinger's memorandum was written to a friendlier correspondent, the President's counsel, and its terms concerned not the President's "duty" but his "authority" - the extent to which he can claim what we might analogize to a qualified privilege to act on his own understandings of the Constitution (and, one might add, the implications of the Court's jurisprudence) in situations that a reasonable observer would not regard as settled by either the text of the Constitution or the decided cases. "Duty" and "authority" address different issuesthe one, what the President must do, as a matter of legal obligation; the other, what he may do, in exercising the authority of his office. One need not choose between them, or seek a middle ground.

Indeed, it is in the nature of wielding executive authority, independent of any issue of constitutionality, that the executive will enforce some statutes rather than (or more completely or aggressively than) other statutes-that it may even find that some have been abandoned by general changes in society or law without having been explicitly repealed. The Constitution, and the Court's attitudes about judicial primacy and finality in constitutional interpretation, add to this natural selectivity an element of compulsion or obligation-but are not, in my judgment, its primary source. The President's own job calls on him to allocate the resources of government, and, again, on the whole, judicial supervision of that allocation is both difficult and hazardous to the enterprise of government. The political, not legal, controls of the election booth, history's regard, and impeachment on the one side, the demands of the Constitution and the system of precedent on the other, set a framework within which these allocations are made. We do live in-we demand-a rule-of-law culture. The Constitution's faithful execution formulas, in this sense, express a hope for presidential commitment and enthusiasm. On the whole, we might rather have

further challenges to objectionable precedent could be justified by the hope that the ruling would be "overruled and never become a precedent for other cases," Abraham Lincoln, First Inaugural Address (Mar. 4, 1861), such resistance has its limits. "When that chance has been exploited and has run its course, with reaffirmation rather than reversal of decision, has not the time arrived when its acceptance is demanded, without insisting on repeated litigation?" Herbert Wechsler, The Courts and the Constitution, 65 COLUM. L. REV. 1001, 1008 (1965). Cf. supra text accompanying note 27 (discussing nonacquiescence).

37. 403 U.S. 388 (1971)

38. See Civiletti Memorandum, supra note 34. 
Presidents who do not test the limits of what they can do, in fighting either Congress or the Court. But the root proposition is that the President does, of necessity, have room for his own provisional judgments about what the Constitution means, and the power to act on those judgments.

Two matters in the news in the weeks leading up to the conference at which these papers were presented illustrated the commonality, the necessity, of such judgments. In The Legal Times of September 13, 1999, a feature article discussed President Clinton's Executive Order $13132^{39}$ as well as pending legislation, both of which would sharply limit the preemptive effect of federal action on state regulation. ${ }^{40}$ The executive order, of particular interest here, directs executive agencies to take "action limiting the policymaking discretion of the [s]tates [through preemptive regulatory action] only where ... the national activity is appropriate in light of the presence of a problem of national significance. ${ }^{\circ 11}$ It further requires the agencies to consult with state and local officials before acting to establish uniform national standards and directs that, "where possible, [they must] defer to the [s]tates to establish standards." ${ }^{22}$ These instructions embed a particular view of the arrangements of federalism-an issue central to our constitutional order-in presidential instructions about how the laws are to be faithfully executed. We can be quite sure that some of the Congresses that enacted statutes empowering agency preemption of state law had a differing view, neither anticipating nor wishing such constraint. In the New York Times of September 26, 1999, another article discussed the recent decision of the United States Court of Appeals for the Fourth Circuit in United States $v$. Dickerson, ${ }^{43}$ which resurrected 18 U.S.C. $§ 3501$, a 1968 statute purporting to overrule Miranda v. Arizona ${ }^{44}$ in federal courts. ${ }^{45}$ Federal prosecutors had ignored that statute and followed Miranda for thirty-one years, on advice from the Attorney General grounded in the belief that the statute was unconstitutional. It was more important, to them, to have police act in a manner that assured sound convictions than to follow a course permitted by statute but judged likely to lead to prosecutorial failures. That advice survived reexamination early in the Reagan Administration. ${ }^{46}$ What is remarkable, as in relation to the executive order, is that there appears to have been no doubt or soul-searching about whether it was appropriate for the Attorney General to give this directive, even though giving it pretermitted judicial resolution of constitutionality for thirty-one years. No prosecutor invoked $\S 3501$; in Dickerson, an amicus

\footnotetext{
39. 64 Fed. Reg. 43,255 (1999).

40. See Robin Conrad \& Jim Wootton, One Economy, Indivisible?, LEGAL TIMES, Sept. 13, 1999,

41. 64 Fed. Reg. 43,255 (1999) (emphasis added).

42. $I d$.

43. 166 F.3d 667 (4th Cir.), cert. granted, 68 USLW 3365 (Dec. 6, 1999) (No. 99-5525).

44. 384 U.S. 436 (1966).

45. See Roger Parloff, Miranda on the Hot Seat, N.Y. TiMES, Sept. 26, 1999 (Magazine), at 84.

46. See id. at 85 (citing ChARles FrIEd, Order AND LAw: ARguing THE REAGAN REVOLUTION-A FIRSTHAND ACCOUNT (1991)).
} at 19. 
was permitted to do so. In the interim, the make-up of the Court and constitutional doctrine have changed such that a statute long characterized as "a patently unconstitutional piece of political grandstanding" may now have a significant chance of being upheld. ${ }^{47}$

One could perhaps find a fruitful analogy for thinking about these issues in Justice Jackson's famous formula in Youngstown Sheet \& Tube v. Sawyer. ${ }^{48}$ Faced there with a claim of inherent presidential authority to take action in the face of national exigency, Justice Jackson suggested a tripartite analysis for judicial assessments of presidential action:

The actual art of governing under our Constitution does not and cannot conform to judicial definitions of the power of any of its branches based on isolated clauses or even single Articles torn from context. While the Constitution diffuses power the better to secure liberty, it also contemplates that practice will integrate the dispersed powers into a workable government. It enjoins upon its branches separateness but interdependence, autonomy but reciprocity. Presidential powers are not fixed but fluctuate, depending upon their disjunction or conjunction with those of Congress. We may well begin by a somewhat over-simplified grouping of practical situations in which a President may doubt, or others may challenge, his powers, and by distinguishing roughly the legal consequences of this factor of relativity.

1. When the President acts pursuant to an express or implied authorization of Congress, his authority is at its maximum, for it includes all that he possesses in his own right plus all that Congress can delegate. In these circumstances, and in these only, may he be said (for what it may be worth) to personify the federal sovereignty. If his act is held unconstitutional under these circumstances, it usually means that the Federal Government as an undivided whole lacks power. ...

2. When the President acts in absence of either a congressional grant or denial of authority, he can only rely upon his own independent powers, but there is a zone of twilight in which he and Congress may have concurrent authority, or in which its distribution is uncertain....

3. When the President takes measures incompatible with the expressed or implied will of Congress, his power is at its lowest ebb, for then he can rely only upon his own constitutional powers minus any constitutional powers of Congress over the matter. Courts can sustain exclusive [p]residential control in such a case only by disabling the Congress from acting upon the subject. Presidential claim to a power at once so conclusive and preclusive must be scrutinized with caution, for what is at stake is the equilibrium established by our constitutional system. ${ }^{49}$

For us, the problem is not one of presidential action, but a decision not to act in the face of congressional authorization or congressional will that the executive do so. Could we suppose similar tripartite advice to a President concerned about his freedom to ignore such directions?

1. When Congress has acted pursuant to an express or implied authorization of the Constitution, taking account of its interpretation by the

47. Id. (quoting Professor Yale Kamisar). But see Dickerson v. United States, 120 S. Ct. 2326 (2000).

48. 343 U.S. 579 (1952).

49. Id. at 635-38 (Jackson, J., concurring). 
courts and the deference owing to its judgments, ${ }^{50}$ its authority is at its maximum, and the President's freedom of action is correspondingly small. He can avoid the conclusion that his oath requires assuring faithful execution of such laws only by demonstrating one of the ordinary reasons for preferring the implementation of other laws to this one-the absence of resources, the corrosive effects of the passage of time, or a conflict of obligations irresolvable by any other means and with reasons supporting the choice he has made.

2. When the Constitution's authorization is uncertain and the courts have been silent or unclear, there is a "zone of twilight" in which he and Congress have concurrent authority to read the Constitution, subtracting that much further from his obligations concerning the execution of statutes that might otherwise be thought to lie in his oath. That oath is to see to the faithful execution of "the laws." He may rely on his reading of the Constitution as well as on the more normal factors, until it has been overtaken by judicial decision.

3. When the Congress has taken measures unmistakably incompatible with the expressed or implied terms of the Constitution, taking account of relevant interpretations by the courts, the President's oath of office requires that he give the Constitution preference.

Of course this way of putting it leaves open the various factors Professor Johnsen has identified, for the difficult middle ground, but it still may permit us to make a bit of progress respecting them.

Thus, there may be certain political advantages to acting so as to secure judicial review on a doubtful point, and it is certainly the case that once judicial resolution has been secured, items will tend to move out of the twilight zone into the brighter-edged territory of options one or three. This is different, however, from a proposition that seems to recur in Professor Johnsen's analysis: that acting to secure review is, in itself, a factor that bears on the President's responsibility under his oath. That proposition subordinates the President as a reader of the Constitution and elevates the judiciary, in a manner difficult to justify in a government of co-equal branches. Constitutional review is a challenging necessity of judicial function under a written constitution, not the judiciary's central, defining function. Moreover, if we imagine a President who has reached one conclusion, particularly a negative conclusion, about constitutionality, his pretending to adopt the opposite view in order to secure judicial re-

50. Published conference papers invariably vary in some respects from what was said at the conference itself. This is the reader's gain from what the authors collectively learn there. The footnoted phrase "and the deference owing to its judgments" is one such product-in this case, from Professor Barron's article. See David Barron, Constitutionalism in the Shadow of Doctrine: The President's NonEnforcement Power, 63 LAW \& CONTEMP. PROBS. 61 (Winter/Spring 2000). His proposition, that the room the courts give Congress for judgment is the product of constitutional imperatives equally applicable to the President, is forceful and persuasive. Like the Court, the President might find that the extent of deference owing congressional judgment varies with the circumstances. 
view is, in itself, arguably a violation of his oath. It can hardly be expected that he will take his pretended view with enthusiasm, so that this is not faithful execution in a full sense; and he will have been a party, in effect, to a friendly suitto setting up litigation for the purpose of having a disputed issue of law resolved, which is in itself an offense to the constitutional function of the judiciary. The Attorneys General who chose not to secure judicial review of 18 U.S.C. $\$ 3501$ by failing to invoke it, because they regarded it as unconstitutional and consequently thought its invocation would obstruct their larger purposes of securing criminal convictions, were acting within the appropriate parameters of their office. ${ }^{51}$

To take this outside the constitutional context for the moment, consider Sullivan v. United States, ${ }^{52}$ a case involving the Soldiers' and Sailors' Civil Relief Act. ${ }^{53}$ This statute required the Department of Justice to represent service members who had been amerced state or local taxes in arguable violation of their special federal status and certain statutory immunities it entailed. Officers of the Department of Justice successfully appeared for the service members in the lower courts and filed a Supreme Court brief in support of the judgment below but, as the Court noted,

[t]he Solicitor General and the Assistant Attorney General in charge of the Tax Division of the Department of Justice have informed the Court, however, that they have not been persuaded by those arguments, and that they do not believe that $\S 514$ was intended to apply to the ordinary retail sales tax and concomitant use tax now imposed by most of the States.

The matter does not figure more largely than this in the Court's brief opinion unanimously reversing the holding below and finding against the service members' immunity tax claims. ${ }^{55}$ Still, a witness to the oral argument vividly recalls that the only (and rather heated) interest the Justices had in the government's oral argument was to know why the government attorney was presenting a position that did not have the endorsement of his superiors. Repeatedly the question was, "Why and how are you here?" Was it "faithful execution" to have pressed the soldiers' and sailors' claims at trial? To appear to support the judgment below when it was challenged in the Supreme Court, but in a manner that virtually assured its reversal? The integrity of the judicial process may be undercut when parties put forward for duty's sake a position to which, in fact, they do not subscribe.

In the case of constitutional litigation, a statute now requires the Attorney General to notify Congress that he will not defend the constitutionality of a statute, and for Congress then to substitute its own attorneys for that purpose..$^{56}$ That practice responds well to the situation in which the Department of Justice,

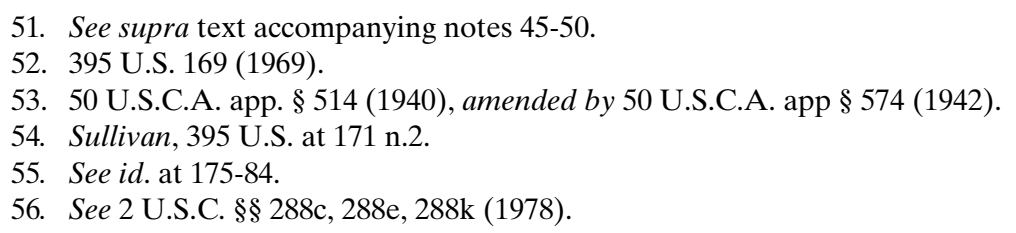


without prior involvement, finds itself having to defend the constitutionality of a statute it cannot in conscience defend. Probably it is better that the Department hand off responsibility than make arguments holding its nose, as it were. But, in the "twilight zone," is the President required by his oath to act against his own constitutional judgment so that Congress's differing judgment will have a day in court? Must he dismiss all, or at least one ${ }^{57}$ HIV-positive serviceman despite his belief that in doing so he is committing an unconstitutional act against a private citizen? Even those who are most dubious about the virtues of judicial constitutional review concede the relative strength of the argument against forced implication in a constitutional violation; Marbury v. Madison $^{58}$ was a strong case for review precisely because the Court was, by hypothesis, being asked to cooperate in a constitutional violation. ${ }^{59}$ President Jefferson relied on similar reasoning to pardon persons convicted under the Alien and Sedition $\operatorname{Acts}^{60}$ and, of particular relevance here, to direct that prosecutions under the Act cease, given his conviction-since vindicated by the verdict of historythat it offended the Constitution's First Amendment. ${ }^{61}$ Congress and the people have their political remedies; the possibility of constitutional review has not become so central that acting to secure it excuses constitutional violations along the way.

57. Might he find out, for example, which HIV-positive member is certain or most likely to find the best lawyer to support him in bringing a challenge to his dismissal, and then delay action on the others pending judicial resolution? Such "test" litigation is often prudent. If it were not done in the situation above, it might be only because of the remedies available against those who spend government funds without authority to do so. Discussion following the presentation of these articles at the symposium strongly suggested that these avenues were explored and that, indeed, the possibility of litigating success for discharged officers-together with the stealth character of the statute in question, offered at 2 a.m. in the final throes of considering budgetary legislation-contributed to Congress's subsequent decision to repeal it.

58. 5 U.S. (1 Cranch) 137 (1803).

59. See id. Notice how Professor Barron's analysis now qualifies this familiar argument-for the Court as well as for the President. See Barron, supra note 50. Both are under a quasi-constitutional obligation to respect Congress's superior judgment on some issues that they might think would render a statute constitutionally suspect. Within the ambit of that obligation to defer, an obligation that varies in intensity with the nature of the constitutional question being raised, neither is in a position to know that it is being implicated in unconstitutionality—and so the strong Marbury argument would be equally unavailable to either.

60. 1 Stat. 596 (1798).

61. In a letter to Abigail Adams on July 22, 1804, President Jefferson wrote:

I discharged every person under punishment or prosecution under the sedition law, because I considered, and now consider, that law to be a nullity, as absolute and as palpable as if Congress had ordered us to fall down and worship a golden image; and that it was as much my duty to arrest its execution in every stage, as it would have been to have rescued from the fiery furnace those who should have been cast into it for refusing to worship the image.

11 THE WRITINGS OF THOMAS JEFFERSON 43-44 (Albert Ellery Bergh ed., 1907). See also his letters of September 11, 1804 to Abigail Adams, id. at 49, and of September 28, 1820, to William C. Jarvis, 15 id. at 276, which are long staples of discussions of this problem. See, e.g., GERALD GUNTHER \& KathleEn M. Sullivan, Constitutional Law 20 (13th ed. 1997). The Alien and Sedition Acts provided that they would cease to be effective on the date of the inauguration of the next President, March 3, 1801, but added that "expiration of the Act shall not prevent or defeat a prosecution and punishment of any offense against the law, during the time it shall be in force." Alien and Sedition Acts, 1 Stat. 596, 597 (1798). Thus, directions to cease prosecuting were as necessary and appropriate as clemency for any who might have been convicted. 
Professor Johnsen makes the appealing argument that presidential nonenforcement on constitutional grounds will distract Congress from its own responsibilities to heed the constitutionality of its actions. By presuming Congress to have acted constitutionally, the President raises the stakes in congressional legislative judgment and avoids "buck-passing" that can be all too easy. Thus, she argues, it was the President's conclusion that he must enforce the HIV statute despite his belief in its unconstitutionality that led Congress to its own responsible withdrawal of that Act. Perhaps, though, the President was impelled to act, not by the purpose of promoting congressional virtue, but by the realization that he could not avoid putting individuals at risk-if not the HIV-infected members of the service, then those who would be party to the continued, statutorily forbidden payment of their salaries. It is no more reasonable to believe that presidential abstention will teach Congress to take more responsibility for its acts - the acts not of an individual, but of a 535-member agglomeration that often acts, as here, with few of its members actually aware of the legislative judgments being made - than it is to think that plain language interpretation will make them better drafters. ${ }^{62}$ Nor can such an attitude be found in the Constitution, which insists on the equality of all branches and, at least under judicial instruction, precludes one branch from acting under hypotheses that disrespect another.

Perhaps the HIV statute also implicates the President's own authority as Commander in Chief and head of the executive branch in general. While the class of HIV-positives is not closed, it has been irrevocably joined for those already in it, and quite possibly in an entirely innocent manner. Congress cannot pass bills of attainder; it cannot force itself upon the President's function of removing officers of the United States for the good of the service. ${ }^{63}$ This is perhaps not so strong an argument, but it permits a moment's consideration of the proposition that the promise of assuring the faithful execution of the laws has special meaning when the President's own authority is at stake, so that his actions involve what might be thought an element of self-defense. At the very least, one could say, this statute requires the President, as he sees it, to embarrass himself in leading the Armed Forces-whichever course would have that

62. As Francis Lieber wrote,

[t]he British spirit of civil liberty induced the English judges to adhere strictly to the law, to its exact expressions. This again induced the law-makers to be, in their phraseology, as explicit and minute as possible, which causes such a tautology and endless repetition in the statutes of that country that even so eminent a statesman as Sir Robert Peel declared, in parliament, that he "contemplates no task with so much distaste as the reading through an ordinary act of parliament." Men have at length found out that little or nothing is gained by attempting to speak with absolute clearness and endless specifications, but that human speech is the clearer, the less we endeavor to supply by words and specifications that interpretation which common sense must give to human words. However minutely we may define, somewhere we needs must trust at last to common sense and good faith.

FRANCIS LIEBER, LEGAL AND POLITICAL HERMENEUTICS 31 (1839).

63. See generally Myers v. United States, 272 U.S. 52 (1926). 
effect in his judgment. ${ }^{64}$ Again what seems relevant to note is that strategic thinking by the President-deciding what course will make it more likely that, ultimately, his view of his own authority will prevail over Congress's-has its own implications for the idea of faithful execution. Duty can be commanded but not enthusiasm, and enthusiasm in particular instances is the more likely as one concludes that one's position is one of equality, independence, and respect.

To paraphrase a remark Richard Posner made about judicial interpretation of statutes, ${ }^{65}$ an irresponsible President will have his way whatever approach we may urge, and a stupid one will blunder. What we are seeking is an understanding suitable for the President of good faith-the President who wants to know what it is his to do. It is in my judgment a considerable mistake to suggest to him a view of "the laws," the faithful execution of which he has undertaken to assure, that is any narrower than the whole as he conscionably and attentively understands them to be. As Professor Barron so thoughtfully suggests, ${ }^{66}$ that understanding will embrace an acceptance of the relevant competences of Congress and courts, each in its respective sphere, but it leaves room as well for the exercise, in that light, of his own.

\footnotetext{
64. A President might conclude that painfully obeying a (perhaps valid) law with which he did not agree was of the essence of leadership in dealing with the military.

65. See Richard Posner, Statutory Interpretation-In the Classroom and in the Courtroom, $50 \mathrm{U}$. CHI. L. REV. 800, 817 (1983).

66. See supra note 50.
} 